\title{
How the Folger Library's Performance-Based Approach to Teaching Shakespeare Affects Critical Thinking
}

\section{Brent T Strom}

\author{
English Faculty, New Trier High School, Winnetka Campus, Winnetka, Illinois, USA
}

stromb@newtrier.k12.il.us

Received Date: July 05, 2017

Accepted Date: July 24, 2017

Published Date: August 14, 2017

Abstract: Shakespeare is the author most taught in American secondary schools, yet no empirical evidence exists to support one methodological approach over another in its teaching.

This study employed the California Critical Thinking Skills Test to measure growth in critical thinking skills that students obtained through a traditional 'seat-bound' versus a 'performance-based' approach to the teaching of Shakespeare at the secondary level. Its purpose was to determine whether there would be a statistically significant difference between the two.

Subjects were selected based on their teacher's methodological approach: one who had learned the performance-based approach from the Folger Library; and the second, a National Board Certified instructor who employed traditional seat-bound methods. Between the two classes there were ninety participants involved in a four-week unit on a particular Shakespeare play $(n=90)$.

Control group students were taught Shakespeare in the traditional manner; experimental group students received the treatment of a performance-based approach. All subjects were given a pre and posttest.

Results indicate that students who learn Shakespeare through a performance-based approach had a statistically significant gain in overall critical thinking skills. This study provides empirical evidence to the benefit of using a performance-based approach in the teaching of Shakespeare at the secondary level.

\section{INTRODUCTION}

Critical Thinking (CT) in educational practice has become a universal term for crafting many state and national standards. Ennis (2008) outlines two different approaches used to define the term: epistemic approaches--a consensus approach that argues CT can be arrived at through various stakeholders including philosophers, policymakers and the individual herself-as championed by Facione (1990), the National Center for Educational Statistics (1995), and Ennis himself (2002); and a second approach, more relativistic, as argued by Fischer and Scriven (1997), Johnson (1996) and Paul (1993), who suggest that CT must be considered dialectic with an emphasis on persuasion, resolution of disputes and context. In either scenario, both groups argue CT "seeks the truth—to try to get it right" (Ennis, 2002, p.8).

In particular, secondary English and Language Arts classrooms grapple with Common Core standards relating to Critical Thinking, fully enveloped in how to promote CT skills for college readiness. Nowhere is this more apparent than in the teaching of Shakespeare, which as the Common Core now requires, must include at the secondary level a full reading of an entire play. American High Schools teach Shakespeare more than any other author (Applebee \& Langer, 2003), but a persistent question remains: what is the best approach to teaching Shakespeare that would in turn affect critical thinking and college readiness for secondary students today? 
The Folger Library believes through its publications, teacher tool kits, and websites, that there is a particular approach to teaching Shakespeare that is more effective than others, beginning with the assumption that teachers must ask themselves what the text 'does' instead of what it 'means' (Rocklin, 1999). Summarized as a 'performance-based' approach to teaching Shakespeare in which students are asked to perform the play in order to access the text, this approach has students on their feet, treating the text as a play to be interpreted, memorizing lines and engaging in verbal language games that play with Shakespeare's lines. Yet, very few studies have enumerated any quantitative benefit for students and educators who employ this method (Riggio, 1999; Rocklin, 1999; Seidel, 2000).

Given the demands of new Common Core standards, coupled with the ever present need to develop and define CT skills, an evaluation of a particular methodology in the field of teaching Shakespeare may be helpful to secondary practitioners.

\section{PURPOSE}

This study assess through a quasi-experimental design the quantitative impact one specific approach to teaching Shakespeare-the performance-based approach as outlined by the Folger Shakespeare Library--has on the secondary language arts classroom. The purpose of this study was to investigate any statistical difference pertaining to gains in critical thinking as defined by the California Critical Thinking Skills Test among high school students who did and who did not experience a four-week performance-based unit. The study did not consider measuring CT using a different approach-for example using advanced math problems, or reading scientific journals. The study focused only on the difference between the two approaches to teaching the Bard. The study had several limitations, therefore, including the time frame used to measure the difference from pre-test to post-test (four weeks). In addition, as Ennis (2008) notes, measuring CT is still highly debatable, even political. This study wanted to further the conversation only as it relates to the teaching of Shakespeare using a performance-based approach.

Measuring critical thinking remains highly elusive. The increase in the use of the term itself has galvanized innumerable studies (over three thousand "hits" on the ERIC database in a ten year period from 1999 to 2009 for empirical studies alone). Johanson (2010) argues that critical thinking is often regarded as a fundamental aim and an overriding ideal of education. The Partnership for $21^{\text {st }}$ Century Skills (2009) also identified critical thinking as a key skill for students today. In the United States, "a national survey of employers, policymakers, and educators found consensus that the dispositional as well as the skills dimension of critical thinking should be considered an essential outcome of an education" (Tsui, 2002, p.740-741).

Most research on critical thinking (CT) is done in the classroom (Abrami, et.al. 2008) because research rarely involves randomization. In practice, the term has come under intense scrutiny in the last ten years as arguments arise to both the epistemic and relativistic approaches. In addition, though Abrami (2008) points out that few would argue with how CT is applicable across disciplines, there is little consensus as to whether CT is dependent upon content (Halliday, 2000; G. Smith, 2002; Ennis, 1989) or is a generalized subject matter entirely of its own (Royalty, 1991; Siegel, 1988). In other words, are we measuring content-specific knowledge like how to do a scansion (formal understanding of iambic pentameter use) of a Shakespearian monologue or are we determining several different interpretations of how to stage that monologue in the secondary classroom?

In the former approach, often referred to as the "specifist" position (Abrami, et.al. 2008, p.1102), "It makes no sense to talk about critical thinking as a distinct subject matter and therefore cannot profitably be taught as such....Without specific subject X, [CT] is both conceptually and practically empty" (McPeck, 1981, p.5). In the latter-how CT is entirely a subject of its own-or the "generalist" position (Abrami, et.al. 2008), the teaching of reasoning fallacies can, and should, says Siegel (1988), be entirely independent of context so that the learner can identity how a solution can be present under any given context. 
Ennis (2008) argues that in measuring CT in education, both traditional validity and reliability suffer from a "public that is generally [un]aware of the meaning shift from the ordinary to the psychometric sense of reliability" (p. 13). The concern, therefore, is often the lack of multidimensionality that personifies CT skills when using traditional educational testing. It is far easier to quantify a scansion reading than an interpretation of a play. In addition, Ennis (2008) argues that traditional educational testing relies too much on "teaching to the test" (p.17). Yeh (2001) concurs that too often rote-factual learning is considered CT in traditional educational testing.

This study chose the California Critical Thinking Skills Test (CCTST) as the instrument to assess critical thinking. Used extensively in both public and private settings, the CCST has most notably been used in the health care industry, primarily nursing, to help evaluate successful practitioners before entering the field. According to Insight, the company that runs the CCTST, the nursing field is one of the most progressive in implementing and maintaining professional development opportunities that relate to direct instruction of CT skills (Bartlett, 2002, p.64). The test has nothing to do with the specifist approach; nothing on the test related to Shakespearian terminology or specific play content.

The California Critical Thinking Skills Test (CCTS), an outcome of the Delphi Report (Facione, 1990), published in 1990 by Peter Facione of the American Philosophical Association, aligns itself with the epistemic approach to CT (p.1). The consensus statement of the Report in part reads:

"The ideal critical thinker is habitually inquisitive, well-informed, trustful of, open-minded, flexible, fair-minded in evaluation, honest in facing personal biases, prudent in making judgments, willing to reconsider, clear about issues, orderly in complex matters, diligent in seeking relevant information, reasonable in the selection of criteria, focused in inquiry, and persistent in seeking results" (p. 2).

As a discipline-neutral, multiple-choice test with an internal consistency of .70 to .71, the CCST has 34 items that test five subscales. The test has also been used to determine cultural biases, clinical competence, professional development effectiveness, and for screening applications ("Measuring", 2013). Lambert and Martin (in Spies and Geisinger, 2010) both found in their reviews in the Mental Measurements Yearbook (2010) that the CCST had adequate psychometric properties that would be appropriately used in determining progress in specialized settings, especially for those test-takers involved in college readiness or an equivalent program.

\section{RESEARCH QUESTION}

This study addressed the following question: Is there a difference in students' critical thinking skills development as measured by the California Critical Thinking Skills Test between those who experienced a performance-based approach to the teaching of Shakespeare versus those who did not?

\section{SAMPLE}

Two schools were chosen to participate in this study based on two highly-qualified faculty members who teach respectively in each district using these two different approaches to a Shakespeare text. One instructor had been chosen to attend the National Endowment for the Humanities summer institute on the teaching of Shakespeare held at the Folger Library; the other instructor was a Nationally-Board Certified Teacher. The college-preparatory schools were also representative of two regions in the United States: the Pacific Northwest and the Midwest. As highly qualified instructors, this study was able to partially control for the expertise of the instructors.

The first instructor employed the teaching methods in her classroom that she learned at the Folger Library Institute, specifically a performance-based approach that embraced student performance of the text. The 
instructor believed in the process of exploring inflection and subtext; speaking aloud the Shakespeare text with multiple interpretations; acting the text to understand character motivation; having students direct each other in the process; rehearsing a scene to ensure fluidity; and finally producing a scene to explore the impact an audience has on the student interpretation. This process is widely disseminated in the Shakespeare Set Free series written by the Folger Library and is the framework for the many games, activities, discussions and projects that are suggested. The performance-based classes consisted of forty-six college preparatory sophomore students $(n=46)$ enrolled in a suburban school approximately thirty miles outside a large, Pacific Northwest city.

Specifically, the instructor for the experimental group had the following plans for her unit. First, she introduced her students to Shakespeare's language through the use of Shakespearean insults, getting students comfortable with the language as well as engaging in the apparent fun of verbal wordplay. Each day in the first two weeks featured a component in which students stood on their feet-either practicing an interpretation of a line, learning how to choreograph a fight scene, or expanding on a host of vocal exercises enumerated at the Folger Institute as well as available in the Shakespeare Set Free series. The key to these activities was the emphasis on 'play'; students were encouraged to experience multiple perspectives of the same activity. The focus on multiplicity therefore emphasized the CT skill of divergent thinking in that students were directly instructed through the process how to approach the problem of interpreting the text. Essentially, a "correct" version or interpretation of a line, scene, act, was never provided. Instead, the freedom of coming to consensus about the possibilities was modeled. Each lesson plan in the first two weeks also featured discussion of the text, pausing to note specific literary metaphors. Each act unfolded over the course of two days, with some scenes specifically highlighted by viewing a movie version of the play. The instructor noted that the entirety of the movie version was never shown.

The last two weeks the experimental group devoted itself to small group time to prepare for final scenes that were then rehearsed and shown to an audience of other students in the school. Each group was responsible for one scene in the play; the instructor worked as coach when students had difficulties understanding a word, or asked for technical assistance on entrance and exits of characters. However, during the process, students had complete autonomy for the interpretation of their scene, the casting of roles, the memorization of lines, and the procurement of costumes.

The second participant utilized 'traditional' seat-bound methods he had learned in his graduate school methods course. His students read the text aloud, watched scenes of the play in a movie version, held discussions, and even participated in a few theatrical games as interlude to the textual analysis. However, the approach to the text was not based on performance: students never chose roles, interpreted any scenes, directed one another, rehearsed, nor memorized lines that would lead to an overall production. Forty-four $(n=44)$ students in this control group were college preparatory freshman enrolled in a suburban high school approximately twenty miles outside a large, Midwestern city.

Specifically, this instructor had the following plans for his unit on Romeo and Juliet. He likewise used theatrical games at the beginning to have students become accustomed to the Elizabethan language. He then had students utilize a graphic organizer to help identify character relationships. He averaged an act every three days, pausing to write critical reflections on certain metaphors routinely discussed in the text. Students were assigned roles to read the text aloud on any given day; often the instructor would volunteer his own voice to add dramatic intensity to their reading and discussion. One fight scene was staged in the class. Students also viewed the entirety of the Lurham film adaptation of Romeo and Juliet (1995).

The culminating projects for the control group were student assignments that ranged from artistic renderings of certain scenes, to newspaper articles imagining the conflict before the play began, to modern-day texting interpretations of the exchanges among Verona's teenagers. Students spent the last two days of the unit presenting these projects. Students did not memorize and/or perform scenes from the play. 
How the Folger Library's Performance-Based Approach to Teaching Shakespeare Affects Critical Thinking

There were therefore a total of ninety participants $(n=90)$ all of whom were randomly assigned to their particular English class based on their schools' scheduling. All the students were required to take the course; none of the students opted out of the intervention. These schools were public, open-enrollment institutions servicing their respective communities.

\section{Statistical Procedure}

Using descriptive statistics, this study identified both the overall and subset of scores on the CCST. The Pair-difference $t$-test (a.k.a. t-test for dependent groups, correlated $t$-test) $\mathrm{df}=\mathrm{n}$ (number of pairs) -1 since it was concerned with the difference between the average scores of a single sample of individuals who are assessed at two different times (with a before and after treatment score). The hypothesis is a one-tailed directional question for it asks if students who experience Shakespeare through performance obtain a higher critical thinking skill score than those students who do not (H0: There is no significant difference between performance and nonperformance groups with respect to critical thinking; HA: Performance scores significantly higher than non-performance with respect to critical thinking). With the assumption of a normal distribution, the study identified the probability of a particular outcome. That level of probability was specified (alpha level, level of significance, $\mathrm{p}$ ) before data was collected ( $\mathrm{p}<.05$ is a common value that was used).

\section{RESULTS}

The first step in the analysis of data was the calculation of means for both the control and experimental groups to establish the comparability between groups. The second step involved a series of $t$ tests to determine, based on the gains in the score between groups, whether the null hypothesis should be accepted or rejected. Each hypothesis was tested to the .05 level of significance.

Table 1 indicates two areas from the California Critical Thinking Skills Test that reflects significance for the Experimental group from Pre-test to Post-test: Deductive Reasoning ( $\mathrm{p}=.066)$ and Inference $(\mathrm{p}=.030)$.

Table 1: Summary of Overall Pretest and Posttest Scores For Both Experimental Groups Combined on the California Critical Thinking Skills Test

\begin{tabular}{|c|c|c|c|}
\hline Category & Pretest & Posttest & p-value \\
\hline Inductive Reasoning & $\begin{array}{l}\bar{X}=9.753 \\
s=2.822\end{array}$ & $\begin{array}{l}\bar{X}=9.663 \\
s=2.806\end{array}$ & .229 \\
\hline Deductive Reasoning & $\begin{array}{l}\bar{X}=10.146 \\
s=3.518\end{array}$ & $\begin{array}{l}\bar{X}=10.910 \\
s=3.236\end{array}$ & .008 \\
\hline Analysis & $\bar{X}=5.247$ & $\begin{array}{l}\bar{X}=5.719 \\
s=1.889\end{array}$ & .016 \\
\hline Inference & $\bar{X}=2.024$ & $\bar{X}=9.022$ \\
& $s=2.816$ & $s=2.856$ & .35 \\
\hline Evaluation & $\bar{X}=5.719$ & $\bar{X}=6.135$ & .024 \\
\hline Total & $s=2.028$ & $s=1.779$ & .026 \\
\hline
\end{tabular}




\section{IMPLICATIONS}

The hypothesis dealt with the overall question of whether studying Shakespeare would improve the critical thinking score as measured by the California Critical Thinking Skills Test using a performance-based approach versus traditional seat-bound methods. A one-paired $t$-test was used to calculate the $p$ value $(0.000)$. This hypothesis was tested by examining the posttest result gains for both groups to determine that indeed studying Shakespeare results in a statistically significant gain in critical thinking as measured by the California Critical Thinking Skills Test for those who experience a performance-based approach.

Unlike the control group, the experimental group results reflect the most change in the subscore regarding Deductive Reasoning, or that skill which directly relates to understanding how the whole relates to the particular. Deductive reasoning is a common thread in literary studies, especially regarding concepts that students may not have been exposed to, like a first-time study of Shakespeare. The Delphi Report argues Deductive Reasoning as: "the overall structure of the argument or intended chain of reasoning" (p. 20). Using a performance-based approach to teaching Shakespeare continually emphasizes how the individual scene, the individual character, the individual choices the student/actor makes, contributes to the entire rendering of the play's interpretive power. A performance-based approach upholds how deductive reasoning skills are emphasized in order to complete the process affectionately termed 'from page to stage' when students are responsible for memorizing and interpreting a scene.

Statistical significance was also found in the subscore of the California Critical Thinking Skills Test relative to Inferencing, which directly relates to understanding how subtext and nuance affect the thinking process. As the Delphi Report explains, Inferencing is that critical thinking skill which "Considers relevant information and to deduce the consequences flowing from data, statements, principles, evidence, judgments, beliefs, opinions, concepts, descriptions, questions, or other forms of representation" (p.22). Using a performance-based approach to teaching Shakespeare emphasizes these skills in particular because of the myriad of choices available to the student/actor when confronted with a scene. Unlike other plays, Shakespeare offers little to no guidance in the form of stage direction other than what is uttered through the character. In the classroom setting and as outlined in the Folger performance-based approach, the experience of learning what the text 'does' instead of what literary analysis 'says' furthers the impact this approach has on critical thinking skills. Students essentially have no other option but to verbalize the different interpretations, especially if they are unfamiliar with the play and/or have not seen movie versions. The experimental group successfully avoided these external influences on the students which would have turned the process into mimicry rather than originality.

The results further inform the debate, begun by O'Brien $(1994,1995,1996)$, that studying Shakespeare at the secondary level through performance has been an important component of the curriculum and to the stated outcomes of language arts classrooms. Coupled with the qualitative benefits, these results enhance the argument that a performance-based approach is an asset to the curriculum decisions made at the secondary level.

O'Brien's $(1994,1995,1996)$ study rendered that students enjoy Shakespeare more through performance; students understand the language better through performance; and that student perception of competence increases due to performance. This study now confirms that students gain important critical thinking skills as a benefit from this approach to teaching Shakespeare.

\section{RECOMMENDATIONS FOR TEACHING}

The history of teaching Shakespeare in America is replete with the constant dialogue of 'to perform' or 'not to perform, that is the question.' It is not a new debate. Though the literature points out specific barriers to the teaching of Shakespeare through performance, it also indicates substantial qualitative benefits to the classroom. There are also many workshops, institutes and publications to help teachers become practitioners 
How the Folger Library's Performance-Based Approach to Teaching Shakespeare Affects Critical Thinking

of the performance-based approach. This study helps confirm the need espoused by advocates of quantitative data to address verifiable benefits for both studying Shakespeare in general and of studying Shakespeare through performance in particular.

The purpose for this study was to determine whether there was a statistically significant difference regarding gains in critical thinking as measured by the California Critical Thinking Skills Test between teaching Shakespeare at the secondary level utilizing performance-based or traditional seat-bound methods. This study found that there was a statistically significant difference, and as such, practitioners, administrators, parents, employers, the government, and all other interested parties in the discussion regarding the need for a $21^{\text {st }}$ century America that can employ critical thinking skills ought to take note.

Table 2: Summary of the Gains from Pretest and Posttest Scores By Experimental Group and Category

\begin{tabular}{|c|c|c|c|}
\hline Category & Control & Experimental & p-value \\
\hline Inductive Resoning & $\begin{array}{l}\bar{X}=0.045 \\
s=2.844\end{array}$ & $\begin{array}{l}\bar{X}=0.117 \\
s=1.895\end{array}$ & .447 \\
\hline Deductive Reasoning & $\begin{array}{l}\bar{X}=0.205 \\
s=3.181\end{array}$ & $\begin{array}{l}\bar{X}=1.091 \\
s=2.187\end{array}$ & .066 \\
\hline Analysis & $\begin{array}{l}\bar{X}=0.205 \\
s=3.181\end{array}$ & $\begin{array}{l}\bar{X}=0.591 \\
s=1.575\end{array}$ & .174 \\
\hline Inference & $\begin{array}{l}\bar{X}=-0.409 \\
s=2.203\end{array}$ & $\begin{array}{l}\bar{X}=0.409 \\
s=1.821\end{array}$ & .030 \\
\hline Evaluation & $\begin{array}{l}\bar{X}=0.455 \\
s=2.005\end{array}$ & $\begin{array}{l}\bar{X}=0.205 \\
s=1.564\end{array}$ \\
\hline Total & $\bar{X}=0.250$ & $\begin{array}{l}\bar{X}=1.205 \\
s=2.985\end{array}$ & .137 \\
\hline
\end{tabular}

\section{REFERENCES}

Abrami, P., Bernard, R., Borokhovski, E.. Wade, A., Surkes, M., Tamim, R., \& Zhang, D. (2008). Instructional interventions affecting critical thinking skills and dispositions: Astage 1 meta-analysis. Review of Educational Research, 78(4), 1102-1134.

Applebee, A., \& Langer, J. (2003). Discussion-based approaches to developing understanding: Classroom instruction and student performance in middle and high school English. American Educational Research Journal, 40(3), 685-730.

Barlett, D. (2002). Measuring change in students' critical thinking ability: Implications for health care education. Journal of Allied Health, 31(2), 64-69.

Ennis, R.H. (2008). Nationwide testing of critical thinking for higher education: Vigilance required. Teaching Philosophy 31, 1-26.

Ennis, R.H. (1989) Critical thinking and subject specificity: Clarification and needed research. Educational Researcher, 18(3), 4-10

Facione, P. (1994). Executive summary. Delphi Report. Santa Clara University.

Gadzella, B.M., Ginther, D.W., \& Bryant, W. (1996) Teaching and learning critical thinking skills. Paper presented at the $26^{\text {th }}$ International Congress of Psychology, Montreal, QC 
How the Folger Library's Performance-Based Approach to Teaching Shakespeare Affects Critical Thinking

Halliday, J. (2000). Critical thinking and the academic vocational divide. Curriculum Journal, 11(2), 159-175.

Johanson, J. (2010). Cultivating critical thinking: an interview with Stephen Brookfield. Journal of Developmental Education, 33(3), 26-30

Kindlon, D. J., Thompson, M., \& Barker, T. (2000). Raising Cain: Protecting the emotional life of boys. New York: Ballantine Books.

McPeck, J. (1981). Critical thinking and education. Oxford, UK: Martin Robinson

Measuring Thinking Worldlwide. (2013). Retrieved April 24, 2013, from Insight Assessment website: http:// www.insightassessment.com/

O’Brien, P. (Ed.) (1994, 1995, 1996). Shakespeare set free: Teaching Romeo and Juliet, Macbeth, Midsummer Night's Dream, Henry IV (Part I), Hamlet, Othello (6 volumes). New York: Washington Square Press.

Partnership for $21^{\text {st }}$ Century Skills (2009) P21 framework definitions. Retrieved April 24, 2013, from Partnership for $21^{\text {st }}$ Century website: http://www.21stcenturyskills.org.

Riggio, M. (1999). Introduction. Teaching Shakespeare through performance. New York: MLA.

Rocklin, E. (1999). Performance is more than an approach to Shakespeare. Teaching Shakespeare through Performance. New York: MLA.

Rocklin, E. (2005). Performance approaches to teaching Shakespeare. Urbana, IL: National Council of Teachers of English.

Royalty, J. (1991). The generalizability of critical thinking: Paranormal beliefs versus statistical reasoning. Journal of Genetic Psychology. 156(4), 477-488.

Seidel, S. (2000). Stand and unfold yourself. Champions of change. MacArthur Foundation: President's Committee on the Arts and Humanities, 80-90.

Siegel, H. (1988). Educating reason: Rationality, critical thinking, and education. New York: Routledge.

Smith, G. (2002). Are there domain-specific thinking skills? Journal of Philosophy of Education, 36(2), 207-227.

Spies, R. A., Carlson, J. F., \& Geisinger, K. F. (Eds.). (2010). The eighteenth mental measurements yearbook. Lincoln, NE: Buros Institute of Mental Measurements

Tsui, L. (2002). Fostering critical thinking through effective pedagogy: Evidence from four institutional case studies. Journal of Higher Education, 73(6), 740-763.

Yeh, S. S. (2001). Tests Worth Teaching To: Constructing State-Mandated Tests that Emphasize Critical Thinking. Educational Researcher. 30(9), 12-17.

Citation: Brent T Strom, "How the Folger Library's Performance-Based Approach to Teaching Shakespeare Affects Critical Thinking". American Research Journal of English and Literature; V3, I1; pp:1-8.

Copyright (C) 2017 Brent T Strom, This is an open access article distributed under the Creative Commons Attribution License, which permits unrestricted use, distribution, and reproduction in any medium, provided the original work is properly cited. 